\title{
MIGRATION PATTERN OF YOUNG PEOPLE IN RURAL (Case Study of young people in Ciasmara Village, Pamijahan District Bogor Regency)
}

\author{
Roni Jayawinangun $^{\text {a) }}$, Muslim ${ }^{\text {a) }}$ \\ a) Universitas Pakuan, Bogor, Indonesia \\ Corresponding Author: winangun_roni@yahoo.com
}

Article history: received 03 January 2019; revised 25 January 2019; accepted 01 February 2019

\begin{abstract}
Low natural resources that support the economy and the inability of people in access is one factor that makes many villagers unable to accumulate capital. Mobilization out of the village is the most logical step taken by villagers to keep them alive. The existence of job opportunities elsewhere and the condition of the village that is no longer conducive will affect the mobility patterns of household members in the village. This research aimed:1) Identify portraits of young villagers on the potential of Ciasmara Village Resources; 2) Identify the driving factors that make young people in rural areas migrate to the city. Quantitative method was used to processed the data using descriptive analysis to know the characteristics of respondents the data processed using the average score is the perception of youth against the village resources and the factors driving and pulling migration. This research found thatPortrait of young people towards Ciasmara Village Resources is generally considered good. In general the attraction of the City is greater than the appeal of the Village. There are four indicators of towing power of the City that is high salaries, the number of job options, the opening of vacancies and work more than one.
\end{abstract}

Keywords: migration pattern, young people, city Attraction

\section{INTRODUCTION}

Low natural resources that support the economy and the inability of people in access is one factor that makes many villagers unable to accumulate capital. Badlands and poor access of the poor to productive economic resources are serious obstacles faced by people who live on site.

Poverty in the countryside can be caused by several factors, but in general, rural poverty due to (1) there are no resources to support the local economy, (2) unequal relationship between stakeholders with the community, and (3) the rural communities loss of viable sources of livelihood. These three things, and certainly still another factor, become a cycle that makes the villagers unable to accumulate capital and get out of poverty.

Another condition that causes the rural poor to increase is the loss of productive economic resources as well as the sources of income in the village. The transfer of land from agricultural land to nonagricultural land is a common practice in rural areas. Like a garden commonly used for planting crops has switched functions to homes.

This situation makes villagers unable to accumulate capital is an unequal relationship between owners of capital with the community, for example is the owner of capital that controls many assets and they apply an unfair labor-employer employment system. Such as irrational exploitation and payment of wages. The irrationality of wages received by the poor allows employers to accumulate capital and inequality increasingly visible.

Poverty in the countryside can be caused by several factors, but in general, rural poverty due to (1) there are no resources to support the local economy, (2) unequal relationship between stakeholders with the community, and (3) the rural communities loss of viable sources of livelihood. These three things, and certainly still another factor, become a cycle that makes the villagers unable to accumulate capital and get out of poverty.

Another condition that causes the rural poor to increase is the loss of productive economic resources as well as the sources of income in the village. The transfer of land from agricultural land to nonagricultural land is a common practice in rural areas. Like a garden commonly used for planting crops has switched functions to homes.

This situation makes villagers unable to accumulate capital is an unequal relationship between owners of capital with the community, for example is the owner of capital that controls many assets and they apply an unfair labor-employer employment system. Such as irrational exploitation and payment of wages. The irrationality of wages received by the poor allows employers to accumulate capital and inequality increasingly visible.

\section{Problem Statement.}

This study basically wants to see how far the migration pattern is done by young people in the village. This great concept will try to be downgraded 
into several operational questions, namely:

1. What about the portrait of young villagers to the potential of Ciasmara Village Resources?

2. Any f actors push and pull that makes young people in rural areas migrate to cities.

\section{Research Objectives}

Based on the problem statement, this research objetives are:

1. Identify portraits of young villagers on the potential of Ciasmara Village Resources .

2. Identify the driving factors that make young people in rural areas migrate to the city

\section{Social Institution}

According to Naim in Hermawan [1], migration is seen as a movement movement from one country to another caused by the individual's own willingness either individually or in groups. All migration studies focus on a resident spec, highlighting what immigrants do in new places. These migrants generally migrate from rural to counseling .

Based on the study of Adinugraha and Herawati [2], there are several patterns of mobilization of rural communities, among others First, Villagers with a large population commuting where workers return home regularly. Workers who do commuting is no longer doing agricultural work because its nonagricultural work is relatively fixed, generally found in the area of Karawang and Indramayu. Second, villages with a large population of circular migration: Can be found in the villages of southern Sulawesi. Although working in non-agricultural sectors such as trading and mining gold, but they still go back to do agricultural jobs especially when the time approaching harvest time. Third, villages where the population is mostly migrated (relatively) 'permanently' both to other cities and abroad. Actually the mobility of these workers is not entirely permanent because (it will tell the story of those who go out of town / country but keep investing to the land, and some still have plans to return to the village, part of the life cycle ).

\section{Driving Factors and Attractor Factors}

Driving (push - out) and attraction (pull-out) is a concept associated with the migration from the village - the city. If no view or notice of geographic shifts, push-outs and pull-outs occur with respect to the type of work, also called job mobility, which translates into the migration of the population from one economic sector to another, eg from agriculture to non- Suryana in Tjakrawati [3]

Migrants come to the city with the hope that one day they will get a job even though $i$ a have a period of unemployment. Thus there are two things that consider the more people working in the non-agricultural sector are: a) the real difference of income between the city and village and b) the amount of employment in the city based on the perception of labor (Singarimbun [4]).

\section{Livelihood Strategy}

The pattern of social relations also contributes to the color of the livelihood strategy. Patron-client relationship pattern is considered as an institution capable of providing security guarantee subsistence of farm household (Crow [5]). Carner in Meiviani and Arsal [6] states that there are several strategies undertaken by the rural poor, among others: (1) performing various jobs despite low wages, (2) utilizing kinship ties and mutual exchange in the provision of security and protection, and (3) migrating to other areas is usually rural-urban migration as the last alternative if there is no choice of livelihoods in the village.

Widodo in Meiviani and Arsal [6], revealed the symptoms of labor migration of agricultural sector to non-agricultural sector through rural-urban migration process.

\section{RESEARCH METHODS}

The study was designed using a descriptivequantitative approach to reveal the reality of the pattern of migration of young people in rural areas in responding to changes in the village.

The location of the study was chosen purposively with some consideration (purposive). Cipendawa Village was Chosen as research location. There are some considerations in selecting Ciasmara Village in Pamijahan Sub- district. The location is selected because it is Tourism Village and is the Village with the largest rice field in Pamijahan District. This research has been conducted from July 2017 to December 2017. The research stages were divided into five main stages: Such as (1) preparing research proposal, (2) Conducting literature study, (3) field research, (4) compilation of research result (5) writing final report.

Data collection is done to obtain the information needed in order to achieve the research objectives. Data collection by several steps, namely:

1. The preliminary survey is the preliminary stage by conducting preliminary observations and research to collect data to strengthen problems that occur in the field so that the research is necessary and workable. Preliminary survey conducted young people in Ciasmara village.

2. Quantitative data collection process by survey method with questionnaire instrument.

The data has been collected, then processed in order to have meaning useful to solve the problem under study. The data analysis used is:

1. Descriptive Analysis is the presentation of data or information from research in the form of images, graphs, and tables of the results of the questionnaire 
and other secondary data. The data is processed using descriptive analysis to know the characteristics of respondents

The average scoring method is used to find out the respondent's perceptions of the statements given in the questionnaire. Presentation of data in order to support and clarify the results of research. the data processed using the average score is the perception of youth against the village resources and the factors driving and pulling migration.

\section{RESULTS AND DISCUSSION}

\section{Youth Portrait Of The Village To Potential Of Ciasmara Village Resources}

Portrait of young people of Ciasmara village in this study, covering the characteristics of young people (gender and education) and perceptions related to the Resource in Ciasmara Village. By gender, it is known that the respondents are dominated by male with a percentage of $85.3 \%$ and $14.7 \%$ of female, this is because the male population in the village of Ciasmara more than female with the percentage of $52 \%$ of the total population. The distribution of respondents by gender and education can be seen in Table 1 .

Table 1 Distribution of Respondents Based on gender and Education Level

\begin{tabular}{|l|c|}
\hline \multicolumn{1}{|c|}{ Characteristics } & Percentage (\%) \\
\hline Gender & 85,3 \\
Female & 14,7 \\
\hline Education & \\
No education & 15,7 \\
Elementary & 45,9 \\
Junior High School & 17,4 \\
Senior High School & 19,8 \\
Bachelor & 1,2 \\
\hline
\end{tabular}

Perceptions related to the Resource in Ciasmara Village are generally considered good by young people are shown with an average value of $89.7 \%$. Of the nine indicators, it is known that there are three indicators whose value is below the average of abundant agricultural products, agricultural market access and availability of water. There three indicators, it is known that agricultural output is seen as a problem of agricultural productivity and market access. The abundance of agricultural land in Ciasmara Village should be a village advantage and can provide employment opportunities for young people in Ciasmara, but in reality the difficulty of market access is a consideration for young people to prefer migration to city. More clearly on perceptions related to Resource of young people's can be seen in Figure 1 .

\section{The Push Factors And Pull Factors Of Young People Migrate To The City}

Push - out and pull-out is a concept associated with the migration from the village - the city. If no view or notice of geographic shifts, push-outs and pullouts occur with respect to the type of work, also called job mobility, which translates into the migration of the population from one economic sector to another, eg from agriculture to non- Suryana in Tjakrawati [3].

Based on the data collected, it is known that the general attractiveness of the City is greater than the appeal of the village as well as the factors driving the village. It is shown by the average value of city attraction factor of 2.57 is greater than the Village of 2.47. It is known that there are four indicators of city pulling is a high salary, the number of job options, the opening of vacancies and work more than one. These four indicators make young people's interest to work in Ciasmara Village which in fact is sustained by agriculture is declining. This result is in line with the findings of the Smeru Research Institute of 2016 which cites the growing allegation of a growing interest in working in agriculture among young people; working in agriculture for the young is not so the main choice. This sector is considered to be competitively weak, if any are interested in farming, because of the latter option or no other employment options (Sadali [7]). More clearly about the perception of young people on the Pull factors of cities and villages can be seen in the following table 2 .

Table 2. Perception of young people on the Pull factors of cities and villages

\begin{tabular}{|c|c|c|c|c|}
\hline No. & Indicators & City & Village & Gap \\
\hline 1. & Ease of finding work & 2,24 & 2,32 & $-0,09$ \\
\hline 2. & Many choices of types of work & 2,88 & 2,62 & 0,26 \\
\hline 3. & Ease of work after school & 2,85 & 2,62 & 0,24 \\
\hline 4. & Ease of work without higher education & 2,41 & 2,56 & $-0,15$ \\
\hline 5. & Variety of job sector choices & 2,59 & 2,59 & 0,00 \\
\hline 6. & Have more than one job & 2,59 & 2,41 & 0,18 \\
\hline 7. & High paying jobs & 2,41 & 2,09 & 0,32 \\
\hline & Average & 2,57 & 2,46 & \\
\hline
\end{tabular}

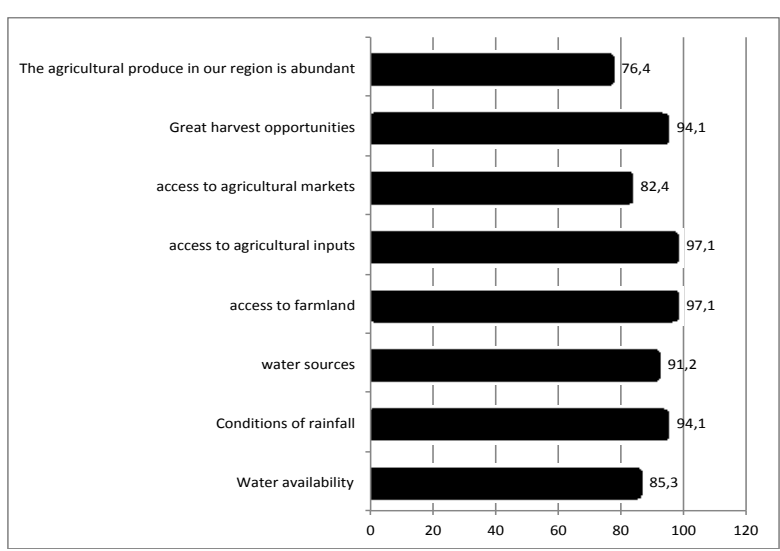

Figure 1. Perceptions young people's related to the Resource in Ciasmara Village

The factors of attractiveness of the village based on the perception of young people is the ease of work. 
Convenience in this case is the requirement of education which is one of the conditions that must be met by job seekers if they want to work in the city, especially in the field of industry by becoming laborers. Basically young people in Ciasmara argue no difficulty in finding work in Ciasmara Village, but the attraction factor of the city is still considered bigger to make young people in Ciasmara Village want to work in the City.

The appeal of other villages and which is the driving force of the city is close to family, felt more comfortable, bored, lower cost of living and more religious. The family's reason is the biggest reason for the young people of Ciasmara Village to work in the Village besides the comfort factor that is felt more than life in Kota. This is as stated by Erdin Hidayat (19 years) and Irfan Mursarip (21 years old) mentions that Working in the Village is more comfortable, if the work in the city is more cramped.

\section{CONCLUSION}

Conclusion in this research are:

1. Potrait young people to Ciasmara Village Resources is generally considered to be good. There are three indicators that need to be considered : agricultural output, market access for agricultural products and water availability.

2. In general the attraction of the City is greater than the appeal of the Village. There are four indicators of towing power of the City that is high salaries, the number of job options, the opening of vacancies and work more than one.

Recommendations for this research are:

1. Need attention in the field of agriculture, especially the problem of productivity and market access, given the extent of agricultural land in the village of Ciasmara well as growing interest in farming young people with the use of modern technology, the diversity of agriculture and improvement of skills and knowledge of agricultural science gained from extension workers and s ekolah agriculture.

2. Optimizing the tourism sector, considering the existing natural tourism potential of Ciasmara Village such as waterfalls or waterfall and hot springs can be a special attraction for young people to work in the village.

\section{REFERENCES}

[1] Hermawan, A. 2002. Factors That Cause Circulatory Migration and the Influence of Circulatory Migration to the Origin of the Region.

[2] Adinugraha, Y and Herawati, R. 2015. Revealing the Reality of Rural Youth in the
Agricultural Sector. Journal of Social Analysis of Akatiga . Bandung.

[3] Tjakrawati, S. 1988. Change of Agricultural Work Value in Rice Field Area; Youth Case in Kampungsawah Village, Rengasdengklok Subdistrict, Krawang Regency [thesis]. Bogor: Graduate School, Bogor Agricultural University.

[4] Singarimbun M, Effendi S. 2010. Survey Research Methods. Jakarta : LP3ES

[5] Crow, G.1989. The Use of Concepts of Strategy in Recent Sociological Literature. Sociology.

[6] Meiviani, Y and Arsal, T. 2015. Sustainable Livelihood Strategies for Poor Households in Coastal Areas. Makara Sosial Humaniora Vol 15.

[7] Sadali, Hariyanti. 2016. Young People's aspirations for working in agriculture. Smeru Research Institut. Newsletter no. 37 accessed http://www.smeru.or.id/sites/default/files/public ation/news37.pdf (8 July 2018) 